\title{
MOTYW DRABINY JAKUBOWEJ (RDZ 28,10-22) W STAROŻYTNEJ SYMBOLICE ZACHODNIEGO CHRZEŚCIJAŃSTWA
}

Biblijny epizod znany pod nazwą „drabiny Jakubowej” pobudzał na przestrzeni wieków wyobraźnię chrześcijan i zachęcał do tworzenia skojarzeń symbolicznych, które nadawałyby mu nowe znaczenia w zmieniających się kontekstach egzystencjalnych właściwych interpretatorom.

Zanim przyjrzymy się, jak opowieść z Rdz 28 zapładniała twórcze intuicje pisarzy z kręgu chrześcijaństwa zachodniego (łacińskiego) aż do Augustyna ${ }^{1}$ zbadajmy na czym polega symbolotwórcza specyfika biblijnej narracji.

\section{Potencjalność symboliczna narracji o „drabinie Jakubowej”}

Zacznijmy od kontekstu szerszego. Epizod „drabiny Jakubowej” wpisuje się w narrację drogi. Jakub wraca z Beer-Szeby do Charan i zatrzymuje się na nocleg. Mamy więc horyzontalny wymiar wędrowania z jednego miejsca do drugiego, który przeplata się z wymiarem wertykalnym, jaki przedstawia drabina łącząca to, co w górze z tym, co na dole. Na tę horyzontalno-wertykalną strukturę nakłada

1 Z najnowszych publikacji poświęconych tej tematyce warto wspomnieć: N. M 111 i n, Stairway to Heaven: Jacob's Ladder as Moral and Religious Instruction in early Medieval Ireland, The History Review 17/2013, s. 92-115. W części wstępnej autor przedstawia zarys historii żydowskiej i chrześcijańskiej interpretacji motywu drabiny Jakubowej. Ojcom Kościoła poświęca s. 97-100, kładąc nacisk na przedstawicieli tradycji wschodniej (Orygenes, Grzegorz z Nazjanzu, Grzegorz z Nyssy, Jan Chryzostom). 
się napięcie pomiędzy dynamizmem ruchu a statyką snu. Jakub wędruje, jest w drodze, podobnie aniołowie z onirycznej wizji wstępują i zstępują po drabinie. Równocześnie jednak mamy układ statyczny: Jakub jest pogrążony we śnie a Bóg stoi nieruchomo na szczycie drabiny $(\mathrm{Rdz} 28,13)$.

Motyw snu stanowi istotny czynnik symbolotwórczy, gdyż wizje oniryczne w każdym kontekście kulturowym stanowiły materiał interpretacyjny. Sen bohatera historii wprowadza czytelnika w przestrzeń znaków i symboli, zachęcając do manipulacji nimi w zależności od własnych priorytetów. Z motywem snu łączy się motyw ciemności. Tekst biblijny wyraźnie podkreśla „gdy słońce już zaszło” (w. 11). Ciemność z kolei wprowadza w przestrzeń tajemnicy: jest coś niewidocznego, ukrytego, co czytelnik ma wyjaśnić, odsłonić.

Pod względem materialnym, dwa motywy wydają się wysuwać na pierwszy plan: kamień i drabina. Motyw kamienia wielokrotnie powraca w perykopie: „Wziął więc z tego miejsca kamień i podłożył go sobie pod głowę” (w. 11), „rano wziął ów kamień, który podłożył sobie pod głowę, postawił go jako stelę” (w. 18), „ten zaś kamień, który postawił jako stelę, będzie domem Boga" (w. 22). Pozytywna symbolika kamienia wiąże się z trwałością, stabilnością, niewzruszonością, co w literackim kontekście perykopy odnosi się do obietnic złożonych przez Boga w ww. 13-15, zaś w kontekście kanonicznym może stanowić odwołanie do symboliki Boga jako skały (Ps 18,32; 31,3-4; 62,3.7, passim) a w szczególności Chrystusa jako kamienia węgielnego (Mt 21,42) i skały towarzyszącej wędrującym Izraelitom, z której tryska źródlana woda (1 Kor 10,4).

Motyw drabiny zawiera w sobie liczne pierwiastki symbolotwórcze. Po pierwsze, jest ona czynnikiem łączącym niebo z ziemią. Ma swoisty wymiar transcendentny i paradoksalny. Jest to „metafizyczna" drabina zespalająca to, co z natury rzeczy jest radykalnie rozdzielone. Ten aspekt dodatkowo wzmacnia obecność aniołów (w. 12). Po drugie, jest przestrzenią komunikacji, wymagającą wysiłku, zarówno w celu wejścia, jak i zejścia. Po trzecie, nie bez znaczenia dla symboliki chrześcijańskiej jest fakt, że materiał, z którego jest wykonana drabina, stanowi drewno, co będzie budziło 
skojarzenia z innymi przedmiotami drewnianymi, zwłaszcza z krzyżem Chrystusa.

Wątek aniołów zstępujących i wstępujących zapraszać będzie komentatorów do podchwycenia przeciwstawnego ruchu: ku górze i ku dołowi, co z kolei będzie miało konsekwencje w symbolice moralnej: ruch ku górze symbolizuje wzrastanie i doskonalenie się, zaś ku dołowi - upadek i grzeszność.

$\mathrm{Na}$ koniec, być może mniej widoczny, jest aspekt przestrzeni domowej, zawarty zwłaszcza w finalnej konstatacji Jakuba: „Prawdziwie jest to dom Boga i brama nieba!” (w. 17). Nie zapominajmy, że drabina w starożytnych domostwach była jednym z najpotrzebniejszych sprzętów. Za wyjątkiem masywnych budowli zaopatrzonych w schody, jedynie dzięki drabinie można było uzyskać dostęp do wyższych kondygnacji. Jeżeli Jakub nazywa miejsce, gdzie miał sen, „bramą nieba”, to właśnie dzięki drabinie możliwe jest wejście do tego domu.

\section{Starożytne interpretacje symboliczne}

Najstarszą aluzję do „drabiny Jakubowej” w starożytnym piśmiennictwie łacińskim znajdujemy w Męczeństwie św. Perpetui i Felicyty (Kartagina, 203 r.). Przebywająca w więzieniu Vibia Perpetua, w oczekiwaniu na męczeństwo, widzi we śnie spiżową (według niektórych rękopisów złotą) drabinę, sięgającą do nieba, po której można wspinać się pojedynczo. Z obu jej stron widać miecze, dzidy i ostrza. U stóp drabiny czyha smok (draco), który odstrasza od wspinaczki, zaś na jej szczycie oczekuje Zbawiciel. Gdy Perpetua postawiła stopę na głowie smoka, jakby na pierwszym szczeblu drabiny, natychmiast ujrzała Chrystusa w raju, otoczonego thumem zbawionych odzianych w białe szaty ${ }^{2}$.

2 Por. Passio SS. Perpetuae et Felicitatis, 1,3; PL 3,25A-27A; tłum. A. M a 1 ino w s ki, w: M. S t a ro w i e y s k i (red.), Męczennicy, Ojcowie Żywi 9, Kraków 1991, s.251-252. 
Wydaje się, że kontekst świadectwa składanego poprzez męczeństwo warunkował najstarszą interpretację symboliczną epizodu o „drabinie Jakubowej”, nadając jej symbolikę moralną. W podobnym bowiem duchu wyraża się Tertulian, gdy explicite pisze, iż „drabina, która śniła się Jakubowi, oznacza wstępowanie jednych ku temu, co w górze i zstępowanie innych ku temu, co w dole"”. Oczywiście obraz „aniołów wstępujących” symbolizuje męczenników, zaś zstępujących - tzw. lapsi, czyli tych, którzy ulegli presji prześladowców i zaparli się Chrystusa. W innym miejscu, dyskutując z Marcjonem, nazywa „drabinę Jakubową" drogą do nieba (iter ad coelum). Ci, którzy wspinają się po niej, docierają (perveniunt) do celu zbawienia, zaś inni z niej spadają (decidant) ${ }^{4}$. Tertulianowe przeciwstawienie „tego, co w górze” „temu, co w dole” może mieć w tle Pawłowe: „Jeśliście więc razem z Chrystusem powstali z martwych, szukajcie tego, co w górze, gdzie przebywa Chrystus zasiadając po prawicy Boga" (Kol 3,1).

W pismach Ambrożego z Mediolanu, który - jak wiadomo - sformułował wiele interpretacji symbolicznych na użytek homiletyczny, odniesienie do drabiny (lub stopni scalae - w języku łacińskim określanych tym samym słowem) pojawia się w Komentarzu do Dwunastu Psalmów Dawidowych. Porównuje on drabinę do Pisma świętego, które zachęca człowieka do wstępowania po stopniach karności ( $\mathrm{gra}$ dus hos ascendere disciplinae) a samo wspinanie się po drabinie jest wznoszeniem się w pobożności (pietatis ascensum). Ambroży rozwija tę myśl, dodając, że pierwszym krokiem na jej szczeblach jest powstrzymanie się od grzechu, a im wyżej się wspinamy, tym bardziej oddalamy się od tego, co ziemskie 5 .

W mowie pośmiertnej na cześć Satyra biskup Mediolanu lakonicznie przedstawia symbolikę drabiny sięgającej nieba jako obrazu krzyża Chrystusowego, dzięki któremu dokonuje się przyszła

T e r t u 1 i a n, De fuga in persecutione, 1; PL 2,103C-D.

4 T e n ż e, Adversus Marcionem, 24; PL 2,357A-B.

5 A m b r o ż y, Enarrationes in XII Psalmos Davidicos, 1,18; PL 14,929B-C. 
wspólnota (futura consortia) pomiędzy aniołami zstępującymi z nieba a ludźmi wstępującymi z ziemi ${ }^{6}$.

W polemicznym dziele skierowanym przeciwko Janowi Jerozolimskiemu, Hieronim przywołuje Orygenesowską interpretację „drabiny Jakubowej” jako obrazu hierarchii racjonalnych stworzeń. Najniższym stopniem drabiny jest „ciało i krew”, zaś wstępowanie lub zstępowanie dokonuje się dzięki reinkarnacji (mutare corpora) ${ }^{7}$. Hieronim wydaje się nie podzielać tej opinii, zresztą podając imię jej autora (docet Origenes), na niego zrzuca odpowiedzialność za jej sformułowanie.

Hieronim opowiada się za dwoma interpretacjami symbolicznymi wizji Jakuba. Pierwsza z nich odnosi się do Bożego miłosierdzia i aż czterokrotnie została potwierdzona w listach pisanych przez Strydończyka. W liście do Furii przywołuje obraz aniołów wstępujących

6 T e n ż e, De excessu fratris sui Satyrus,100; PL 16,1244D-1344A. Tradycja na przestrzeni wieków przypisywała Ambrożemu średniowieczny Komentarz do Apokalipsy, w którym znajdujemy oryginalną interpretację „drabiny Jakubowej”. Anonimowy autor rozbiera drabinę ,na czynniki pierwsze”: składa się ona z dwóch pionowych drewnianych żerdzi, które symbolizują dwa przykazania miłości Boga i bliźniego oraz licznych poprzecznych stopni, oznaczających poszczególne cnoty chrześcijańskiego życia. Ponadto fakt, że drabina podstawą dotyka ziemi a wierzchołkiem nieba, przypomina, iż miłość rozpoczyna się na ziemi, gdy jednoczy nas z bliźnimi, dosięga zaś nieba, gdy jednoczy z Bogiem (Sicut scala ex una parte terram, ex altera coelum tangere visa est, ita et charitas ab inferioribus proximis, a superioribus vero Deo conjungitur, Pseudo-Ambroży, Expositio in Apocalypsim, 6,2; PL 17,820D-821B). Gdy anonimowy autor porusza temat aniołów wstępujących i zstępujących, nadaje im jednak odmienne znaczenie, niż u Tertuliana. Obie kategorie aniołów, którzy symbolizują ludzi świętych, mają znaczenie pozytywne: ci, którzy wstępują, wznoszą się ku miłości Boga dzięki łasce kontemplacji, natomiast ci, którzy zstępują, z miłością pochylają się nad potrzebami bliźnich. W tym samym komentarzu znajdujemy interpretację kamienia, na którym Jakub oparł swoją głowę. Kamień ten symbolizuje Chrystusa, który zgodnie z 1Kor 3,12 jest fundamentem duchowej budowli chrześcijańskiego życia. Komentator wyjaśnia dalej, że jeżeli kładziemy głowę na tym właśnie kamieniu, to znaczy, że na Chrystusie budujemy ściany (w myśl przypowieści o domu na skale z Mt 7,24-27), dzięki spełnianiu dobrych czynów.

7 H i e r o n i m, Contra Joannem Hierosolymitanum, 19; PL 23,370B-C. 
i zstępujących po drabinie sięgającej nieba, którzy symbolizują Boga wyciągającego pomocną dłoń, by podtrzymać upadających ${ }^{8}$. Podobną myśl zawarł w liście do Eustochium, używając nawet tego samego sformułowania porrigens manum (wyciągając rękę), dodał jednak również możliwość sytuacji przeciwnej: Bóg nie tylko pomaga we wspinaczce, ale również strąca $\mathrm{z}$ wierzchołka drabiny tych, którzy lekceważą Jego przykazania (et negligentes de sublimi praecipitans) ${ }^{9}$. W liście do Juliana aspekt położony został na wsparciu udzielanym przez Boga upadłym, aby podjęli wysiłek wspinaczki ${ }^{10}$, zaś w liście do Ageruchii aniołowie wstępują i zstępują, aby ,grzesznik nie tracił nadziei na zbawienie a człowiek prawy nie czuł się bezpieczny w swojej cnocie" (ut nec peccator desperet salutem, nec justus in sua virtute securus sit) ${ }^{11}$.

Druga interpretacja Hieronimowa ma charakter skrypturystyczny. Pisząc do papieża Damazego, Hieronim wyjaśnia, że drabina złożona z dwóch pionowych żerdzi połączonych stopniami symbolizuje ścisłe połączenie Starego i Nowego Testamentu ${ }^{12}$. Hieronim nie rozwija tej symboliki, lecz przedstawia ją w jednym ciągu z innymi obrazami, mającymi tę samą wymowę, mianowicie szczypce z Iz 6,6, obosieczny miecz z Hbr 4,12, dwie monety wdowy z Mk Łk 21,2, stater znaleziony w pyszczku ryby przez Piotra z Mt 17,27, stanowiący podatek za dwie osoby. Tę samą symbolikę znajdujemy w Komentarzu do Ezechiela. Tu jednak Hieronim dodaje jeszcze, iż drabina Jakubowa może też oznaczać spójność Ewangelii, które jednym końcem dotykają ziemi, drugim zaś kierują się ku niebu ${ }^{13}$.

Interpretacja pionowych żerdzi „drabiny Jakubowej” jako Nowego i Starego Testamentu powraca wielokrotnie w Traktatach Zenona $\mathrm{z}$ Werony. Jej szczeble stanowią przykazania ewangeliczne,

\footnotetext{
T e n ż e, Epistola 54 ad Furiam, 6; PL 22,553.

9 T e n ż e, Epistola 108 ad Eustochium, 13; PL 22,888.

10 T e n ż e, Epistola 118 ad Julianum, 7; PL 22,966.

11 T e n ż e, Epistola 123 ad Ageruchiam, 15; PL 22,1056-1057.

12 T e n ż e, Epistola 18 ad Damasum, 14; PL 22,370.

13 T e n ż e, Commentaria in Ezechielem, ad 1,15; PL 25,27D-28A.
} 
których wypełnianie umożliwia wznoszenie się ku niebu' ${ }^{14}$, bądź też poszczególne cnoty życia chrześcijańskiego, które Zenon wymienia w następującej kolejności, poczynając od najniższych: nawrócenie, posłuszeństwo, rozumność, zawierzenie, bojaźń, mądrość, trzeźwość, łagodność, umiarkowanie, czystość, pobożność, miłość, wiara, prawda, pokora, łaskawość, uczciwość, prawdomówność, cierpliwość, wytrwałość, doskonałość ${ }^{15}$.

U Zenona z Werony znajdujemy też najstarsze odniesienie „drabiny Jakubowej" do krzyża Chrystusa. Zenon kojarzy obraz drabiny ze słowami Psalmu 22,4 - „kij Twój i laska pasterska są moją obroną" - otóż owe virga et baculus, wykonane z tego samego tworzywa co drabina, skrzyżowane tworzą krzyż Zbawiciela, dzięki któremu cała ludzkość, począwszy od Adama, ma otwartą drogę do nieba ${ }^{16}$.

Augustynową interpretację „drabiny Jakubowej” zacznijmy od interesującego rozróżnienia, jakie znajdujemy w objaśnieniach do Psalmu 119. Biskup Hippony zauważa, że można (za Tertulianem) odczytywać pozytywnie aniołów, którzy wstępują po drabinie, negatywnie zaś tych, którzy zstępują. Sam jednak opowiada się za pozytywną symboliką zarówno jednych, jak i drugich (forte melius intelliguntur omnes boni in illis scalis, et ascendentes et descendentes) ${ }^{17}$. Dla poparcia swojego stanowiska dodaje, że nie „spadają” oni z drabiny, ale „schodzą”. Nie postępują jak Adam, który „upadł” (cecidit), ale jak Chrystus, który „zstąpił” (descendit).

Drugą cechą charakterystyczną interpretacji Augustyna jest ścisłe powiązanie omawianego przez nas epizodu z Księgi Rodzaju z tekstem J 1,51: „Zaprawdę, zaprawdę, powiadam wam: Ujrzycie niebiosa otwarte i aniołów Bożych wstępujących i zstępujących na

\footnotetext{
4 Z e n o n z W e r o n y, Tractatus 13,1; PL 11,428A.

15 T e n ż e, Tractatus 13,5; PL 11,433A-B.

16 T e n ż e, Tractatus 13,3.5; PL 11,431A-B.433B.

17 A u g u s t y n, Enarrationes in Psalmo 119,2; PL 37,1598.
} 
Syna Człowieczego"18. Interpretując obraz wstępujących i zstępujących aniołów, Augustyn nadaje im symboliczne znaczenie głosicieli Ewangelii. Pierwszymi z nich są Ewangeliści. Oni to wstępują ku niebu, gdy głoszą: „Na początku było Słowo, a Słowo było u Boga i Bogiem było Słowo” (J 1,1), zstępują zaś, gdy nauczają, że „Słowo stało się Ciałem i zamieszkało między nami” $(\mathrm{J} 1,14)^{19}$ oraz ,narodził się z niewiasty, narodził się pod Prawem, aby odkupić tych, którzy podlegają Prawu" $(\mathrm{Ga} 4,5)^{20}$. W szczególności głosicielem Ewangelii jest św. Paweł Apostoł. Wstępuje on ku górze w słowach: „Znam człowieka w Chrystusie, który przed czternastu laty został porwany aż do trzeciego nieba - czy w ciele, nie wiem, czy poza ciałem, też nie wiem, Bóg to wie - i słyszał tajemne słowa, których się nie godzi człowiekowi powtarzać" (2 Kor 12,2-4), zstępuje zaś, gdy pisze: „Nie mogłem, bracia, przemawiać do was jako do ludzi duchowych, lecz jako do cielesnych, jak do niemowląt w Chrystusie. Mleko wam dałem, a nie pokarm stały" (1 Kor 3,1-2) ${ }^{21}$. Dwukrotnie też przytacza Augustyn zdanie św. Pawła: ,Jeśli bowiem odchodzimy od zmysłów to ze względu na Boga, jeżeli przytomni jesteśmy - to ze względu na was" (2 Kor 5,13), w którego pierwszej części wyrażone zostało wstępowanie, w drugiej zaś - zstępowanie ${ }^{22}$.

Dynamika wstępowania i zstępowania obecna jest w Kościele, gdy chrześcijanie wstępują ku jego głowie, którą jest Chrystus oraz zstępują ku najniższym jego członkom ${ }^{23}$. Pięknie ilustruje to biskup Hippony obrazem matki, która pochyla się nad dziecięciem oraz ojca, który choćby był „wspaniałym mówcą którego głos targałyby

18 T e n ż e, De civitate Dei, 16,38,2; PL 41,517; t e n ż e, Enarrationes in Psalmo 44, 20; PL 36,507; t e n ż e, Sermones de Scripturis, 89,5; 122,2,2; 122,5,5; PL 38,557.681.683; t e n ż e, Contra Faustum Manichaeum, 26; PL 42,268; t e n ż e, In Ioannis Evangelium tractatus, 7,23; PL 35,1449-1450.

19 T e n ż e, Enarrationes in Psalmo 44, 20; PL 36,507.

20 T e n ż e, Contra Faustum Manichaeum, 26; PL 42,268.

${ }_{21} \mathrm{~T}$ e $\mathrm{n} \dot{z} \mathrm{e}$, In Ioannis Evangelium tractatus, 7,23; PL 35,1449.

22 T e n ż e, Enarrationes in Psalmo 44, 20; PL 36,507; t e n ż e, Contra Faustum Manichaeum, 26; PL 42,268.

23 T e n ż e, Enarrationes in Psalmo 44, 20; PL 36,507. 
forami i wstrząsał trybunałami" (sit tantus orator ut lingua illius fora concrepent et tribunalia concutiantur), to jednak ,jeśli ma maleńkiego syna, powróciwszy do domu, porzuca oratorską elokwencję, dzięki której wstępował ku górze, by dziecięcym językiem zniżyć się ku maleństwu" (si habeat parvulum filium, cum ad domum redierit, deponit forensem eloquentiam quo ascenderat, et lingua puerili descendit ad parvulum $)^{24}$.

Augustyn zwraca również uwagę na ostatnie słowa J 1,51: ,aniołów Bożych wstępujących i zstępujących na Syna Człowieczego". Profetyczną zapowiedzią Chrystusa jest w epizodzie o „drabinie Jakubowej” kamień znajdujący się u podnóża drabiny, na którym Patriarcha oparł głowę. Nasz komentator zwraca uwagę, że w opowiadaniu z księgi Rodzaju Jakub „wstawszy rano, wziął ów kamień, który podłożył sobie pod głowę, postawił go jako stelę i rozlał na jego wierzchu oliwę" (Rdz 28,18). Gest rozlania oliwy, czyli namaszczenia, przywołuje etymologię słowa Chrystus, czyli „Namaszczony”, dlatego też kamień ów symbolizuje Jezusa ${ }^{25}$. Na zasadzie reminiscencji, zestawia więc motyw kamienia z epizodu o śnie Jakuba z cytatem z Ps 118,22 (,Kamień odrzucony przez budujących stał się kamieniem węgielnym”) 26, z Iz 28,16 („Oto Ja kładę na Syjonie kamień, kamień dobrany, węgielny, cenny, do fundamentów założony. Kto wierzy, nie potknie się"), nadając im sens chrystologiczny, zaś z Nowego Testamentu przytacza 1P 2,4 (,On jest żywym kamieniem, odrzuconym wprawdzie przez ludzi, ale u Boga wybranym i drogocennym").

Do omówionych powyżej autorów warto dodać Hilarego z Poitiers, który nawiązuje do motywu drabiny Jakubowej w swoim dziele o Trójcy Świętej ${ }^{27}$. Przedstawia tam historię snu patriarchy jako jeden z epizodów starotestamentowych, który należy interpretować

$24 \mathrm{~T}$ e $\mathrm{n} \dot{z} \mathrm{e}$, In Ioannis Evangelium tractatus, 7,23; PL 35,1449.

25 T e n ż e, De civitate Dei, 16,38,2; PL 41,517; t e n ż e, Enarrationes in Psalmo 44, 20; PL 36,507; t e n ż e, Sermones de Scripturis, 89,5; PL 38,557; t e n ż e, Contra Faustum Manichaeum, 26; PL 42,268; t e n ż e, In Ioannis Evangelium tractatus, 7,23; PL 35,1449.

26 T e n ż e, Enarrationes in Psalmo 44, 20; PL 36,507.

$27 \mathrm{Hi} 1$ a ry z Poitiers, De Trinitate, 5,20. 
jako zapowiedź ewangeliczną. W tym sensie przekonuje adresatów swego dzieła, że Bóg - zasiadający na szczycie drabiny - jest tożsamy z Jezusem Chrystusem ${ }^{28}$. Jednak interpretacja Hilarego nie zawiera elementów symbolicznych i dlatego zostaje przez nas potraktowana marginalnie.

$$
* * *
$$

Epizod z Księgi Rodzaju o „drabinie Jakubowej” inspirował w starożytnym chrześcijaństwie wielorakie interpretacje symboliczne. Najczęściej spotykamy symbolikę o charakterze moralnym, która zasadniczo przebiega w dwóch kierunkach. Za Tertulianem aniołowie zstępujący symbolizują grzeszników, wstępujący zaś - ludzi prawych. Za Augustynem natomiast, zstępujący oznaczają tych, którzy pochylają się nad potrzebami bliźnich, wstępujący tych, którzy kierują swe serca ku Bogu. Dla Hieronima wstępujący i zstępujący aniołowie symbolizują nie tyle ludzi, ile raczej miłosierdzie Boga, który zniża się ku grzesznikowi. Natomiast dla Ambrożego i Zenona z Werony drabina obrazuje Stary i Nowy Testament, zaś jej szczeble - poszczególne cnoty chrześcijańskiego życia. Ważnym motywem literackim w opowiadaniu o „drabinie Jakubowej” jest też kamień pod głową patriarchy, który w tradycji chrześcijańskiej przyjmuje znaczenie chrystologiczne.

\section{ks. Krzysztof BARDSKI}

Słowa kluczowe: Biblia, drabina Jakubowa, symbol, interpretacja

Keywords: Bible, Jacob's ladder, symbol, interpretation

28 Filius ex alio viso Iacob Deus verus ostenditur. Deus non intelligitur nisi per Deum. Tenet adhuc sacramenti evangelici ordinem legis umbra, et apostolicae doctrinae veritatem mysteriis suis veri aemula praefigurat; tamże. 


\section{The Motif of Jacob's Ladder (Gen 28:10-22) in the Ancient Symbolism of Western Christianity}

Summary

The episode of "Jacob's ladder" in the book of Genesis inspired numerous symbolic interpretations in ancient Christianity. Most often we find moral symbolism, which basically proceeds in two directions. After Tertullian, "descending angels" symbolise sinners, and "ascending" ones symbolise righteous people. After Augustine, "descending" means those who care about the needs of others, whilst "ascending" refers to those who direct their hearts to God. For Jerome, ascending and descending angels symbolise not so much people as the mercy of God who descends to the sinner, whereas for Ambrose and Zeno of Verona the ladder depicts the Old and New Testament and its rungs, namely the Christian virtues. An important literary motif in the story of "Jacob's ladder" is the stone under the Patriarch's head, which in the Christian tradition assumes a Christological meaning. 